Figure:

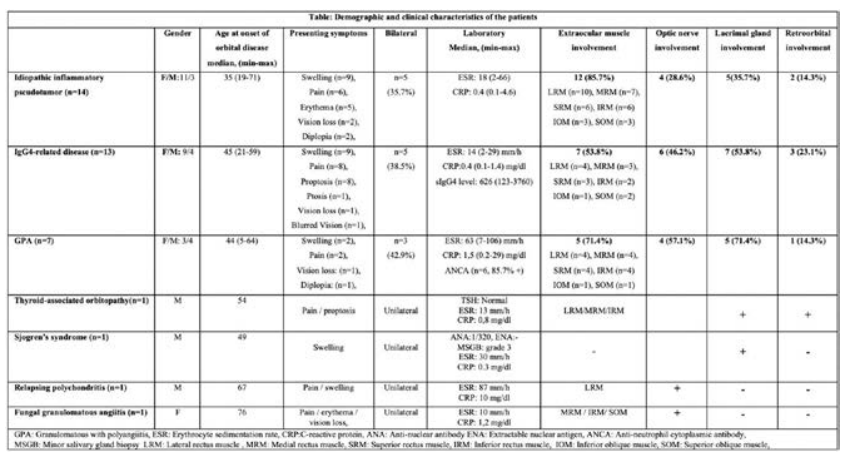

Disclosure of Interests: Melek Seren Aksun: None declared, Taha Koray Sahin: None declared, Ertugrul Cagri Bolek: None declared, Levent Kılıç: None declared, Elif Günay Bulut: None declared, Kader Karlı Oğuz: None declared, Umut Kalyoncu Consultant of: Abbvie, Amgen, Janssen, Lilly, Novartis, UCB, Omer Karadag: None declared

DOI: 10.1136/annrheumdis-2020-eular.6446

\begin{tabular}{|l|l}
\hline AB1039 & LL-37, IL-36, GALECTIN-3 AND TLR-3 LEVELS IN \\
IDIOPATHIC GRANULOMATOUS MASTITIS
\end{tabular}

U. Aydin ${ }^{1}$, B. Oz ${ }^{2}$, A. Karatas ${ }^{2}$, M. Gur², R. Piskin Sagir², G. Artas ${ }^{3}$, S. Aydin ${ }^{4}$, S. S. Koca ${ }^{2} .{ }^{1}$ Firat University, Rheumatology, Elazig, Turkey; ${ }^{1}$ Firat University, Rheumatology, Elazig, Turkey; ${ }^{3}$ Firat University, Pathology, Elazig, Turkey; ${ }^{4}$ Firat University, Biochemistry and Clinical Biochemistry (Firat Hormones Research Group), Elazig, Turkey

Background: Idiopathic granulomatous mastitis (IGM) is a non-infectious inflammatory disorder of the breast characterized by non-caseous granulomas. It is a chronic granulomatous inflammatory disease frequently seen in young fertile women, the cause of which has not been clearly understood. Immunosuppressive agents and surgical interventions are used in the treatment.

LL-37 is a cathelicidin-derived antimicrobial peptide with immunomodulatory properties that are effective in innate immunity. In addition, IL-36, galectin-3, TLR-3 are effective in autoimmunity with proinflammatory properties.

Objectives: With this study, we aimed to investigate the potential alterations of LL-37, IL 36, Galectin 3 and TLR-3 levels in IGM.

Methods: 35 female patients with biopsy-confirmed IGM and 35 healthy controls were included in the study. The serum samples of the subjects LL-37, IL 36, Galectin 3 and TLR-3 levels were studied using the Elisa method. While studying LL 37 and Galectin 3 levels in the tissue, samples of 10 patients who underwent mammoplasty for cosmetic reasons were used for the control group. Ten patients whose paraffin blocks were eligible for re-study were included in the study for tissue examinations. Based on the prevalence $(0.1:<\% 25,-0.4: \% 26-50,0.6: \% 51-75,0.9: \% 76-100)$ and severity ( 0 : no, +0.5 : very little, +1 : little, +2 : medium, +3 : severe) of immunoreactivity in staining, histoscore was created (histoscores = prevalence $\mathrm{x}$ severity)

The data were evaluated using appropriate statistical analysis and $p<0.05$ was considered statistically significant.

Results: When the patient and control groups included in the study were com pared, there was no significant difference in age. In serum samples, LL 37, IL 36, Galectin 3 and TLR 3 levels were statistically significantly lower in IGM group compared to the control group ( $p<0.001$ for each) (Table-1). In biopsy samples, LL 37 level was found to be significantly lower in IGM group compared to the control group ( $p<0.001$ ). However, no significant difference was detected in Galectin 3 levels in tissue studies (Table-2).

Conclusion: In our study, we found that the levels of LL 37, IL 36, Galectin 3 and TLR 3 decreased in serum samples in IGM disease whose etiology was not clearly understood. In addition, we showed that in patients with IGM, LL 37 levels decreased at the tissue level. Studies have shown that in cases of severe sarcoidosis, LL 37 deficiency is reduced both in level and gene expression. So they thought, deficiency of cathelicidin LL 37 may impede resolution of inflammation in the tissue of patients with severe form disease.

References:

[1] Barna, Barbara $P$ et al. "Alveolar macrophage cathelicidin deficiency in severe sarcoidosis." Journal of innate immunity vol. 4,5-6 (2012): 569-78.

[2] Al-Khaffaf, Bilal et al. "Idiopathic granulomatous mastitis: a 25-year experience." Journal of the American College of Surgeons vol. 206,2 (2008): 269-73.

Table 1. LL 37, IL 36, Galectin 3 and TLR 3 levels in serum samples

\begin{tabular}{lccc}
\hline & IGM (N:35) & CONTROL (N:35) & P \\
\hline Age & $35,92 \pm 5,19$ & $34,03 \pm 3,81$ & 0,08 \\
LL 37 (ng/ml) & $5,20 \pm 5,48$ & $40,05 \pm 31,97$ & $<0,001$ \\
IL 36 $(\mathrm{pg} / \mathrm{ml})$ & $294,74 \pm 125,94$ & $864,71 \pm 442,39$ & $<0,001$ \\
Galectin 3 $(\mathrm{ng} / \mathrm{ml})$ & $3,61 \pm 3,16$ & $15,53 \pm 10,14$ & $<0,001$ \\
TLR 3 $(\mathrm{pg} / \mathrm{ml})$ & $931,49 \pm 443,86$ & $4019,36 \pm 2599,51$ & $<0,001$ \\
\hline
\end{tabular}

IGM: Idiopathic granulomatous mastitis

Table 2. Evaluation of LL-37 and Galectin 3 levels with histoscores in biopsy samples

\begin{tabular}{lccc}
\hline & IGM (N:10) & CONTROL (N:10) & $P$ \\
\hline LL 37 & $0,006 \pm 0,025$ & $0,140 \pm 0,516$ & $<0,001$ \\
Galectin 3 & $0,293 \pm 0,201$ & $0,400 \pm 0,290$ & 0,32 \\
\hline
\end{tabular}

Disclosure of Interests: None declared

DOI: 10.1136/annrheumdis-2020-eular.5806

\section{AB1040 COEXISTENCE OF DEMYELINATION DISEASE AND FAMILIAL MEDITERRANEAN FEVER}

C. Korkmaz ${ }^{1}$, D. Üsküdar Cansu ${ }^{1}$, S. Canbaz Kabay ${ }^{2} .{ }^{1}$ Eskişehir Osmangazi University, Eskisehir, Turkey, Department of Internal Medicine, Division of Rheumatology, Eskişehir, Turkey; ${ }^{2}$ Kütahya Dumlupınar University, Kütahya, Turkey, Neurology, Kütahya, Turkey

Table 1. Some clinical and laboratory features of patients with FMF or MEFV mutations accompanied by demyelination disease

\begin{tabular}{|c|c|c|c|c|c|c|}
\hline Cases & Age/Sex & Diseases & MEFV mutations & $\begin{array}{l}\text { The onset age/ } \\
\text { diagnostic age } \\
\text { for FMF }\end{array}$ & $\begin{array}{l}\text { The onset age for DD/MS/ } \\
\text { Presenting manifestations/MRI } \\
\text { findings }\end{array}$ & $\begin{array}{c}\text { Treatment for FMF / } \\
\text { DD/MS }\end{array}$ \\
\hline $\begin{array}{l}\text { Case } 1 \\
\text { (F1) }\end{array}$ & $17 / F$ & $\mathrm{FMF}+\mathrm{DD}$ & M694V homozygous & $3 / 5$ & $\begin{array}{l}15 \\
\text { OB (-) } \\
\text { Fusiform plaques in the cingulate } \\
\quad \text { gyrus; plaques in T4-6 }\end{array}$ & $\begin{array}{l}\text { Colchicine } \\
\text { IL-1 RA } \\
\text { Glatiramer acetate }\end{array}$ \\
\hline $\begin{array}{l}\text { Case } 2 \\
\text { (F1) }\end{array}$ & $46 / F$ & $\mathrm{FMF}+\mathrm{MS}$ & M694V homozygous & $8 / 9$ & $\begin{array}{l}28 \\
\text { Optic nerve involvement } \\
\mathrm{OB}(+) \\
\text { Plaques }(+)\end{array}$ & $\begin{array}{l}\text { Colchicine } \\
\text { Glatiramer acetate }\end{array}$ \\
\hline $\begin{array}{l}\text { Case } 3 \\
\text { (F1) }\end{array}$ & $17 / F$ & $\mathrm{FMF}+\mathrm{MS}$ & M694V heterozygous & $3 / 5$ & $\begin{array}{l}15 \\
\text { Loss of the right eye, vertigo } \\
\mathrm{OB}(+) \\
\text { Plaques }\end{array}$ & $\begin{array}{l}\text { Colchicine } \\
\text { Pulse steroid } \\
\text { Beta-interferon } \\
\text { Teriflunomide }\end{array}$ \\
\hline $\begin{array}{l}\text { Case } 4 \\
(\mathrm{~F} 2)\end{array}$ & $36 / F$ & MS+MEFV mutation & M694V/R202Q & - & $\begin{array}{l}27 \\
\text { Headache, blurred vision, optic } \\
\text { nerve atrophy } \\
\mathrm{OB}(+) \\
\text { Plaques (+) }\end{array}$ & Glatiramer acetate \\
\hline $\begin{array}{l}\text { Case } 5 \\
(\mathrm{~F} 2)\end{array}$ & $16 / F$ & $\begin{array}{l}\text { MS?+FMF+Cutaneous } \\
\quad \text { vasculitis }\end{array}$ & M694V/R202Q & $16 / 16$ & $\begin{array}{l}11 \\
\text { Headache, blurred vision } \\
\text { No LP (denied by pt) } \\
\text { Plaques }\end{array}$ & - \\
\hline
\end{tabular}

